NOTE

\title{
Internal bioerosion by macroborers in Pocillopora spp. in the tropical eastern Pacific
}

\author{
Edgardo Londoño-Cruz ${ }^{1,2, *}$, Jaime R. Cantera ${ }^{2}$, Gerardo Toro-Farmer ${ }^{2}$, Carlos Orozco ${ }^{2}$ \\ ${ }^{1}$ Amakusa Marine Biological Laboratory, Kyushu University, Tomioka, Reihoku-cho, Amakusa, Kumamoto-ken 863-2507, Japan \\ ${ }^{2}$ Universidad del Valle, Departamento de Biología, Apartado Aéreo 25360, Cali, Colombia
}

\begin{abstract}
Bioerosion of branched corals was assessed in a fringing reef (Playa Blanca) and a patch reef (Gorgonilla) of Gorgona Island in the tropical eastern Pacific. Cylinder-shaped experimental units (EUs), made from branches of Pocillopora spp., were set $50 \mathrm{~cm}$ above the sea bottom for 6,12 and 18 mo in Playa Blanca (4 zones: Back Reef, Reef-Flat Crest, Reef Front and Reef Slope) and the Gorgonilla patch reef. Borers were represented by bivalves Lithophaga spp. and Gastrochaena ovata, polychaetes, sipunculids and cirripeds (order Acrothoracica). Lithophaga spp. were the main borers and cirripeds were abundant mainly during the first period of exposure. The highest bioerosion rates were recorded in the Gorgonilla patch reef and the Reef Front of Playa Blanca (2.03 and $1.52 \mathrm{~kg} \mathrm{CaCO} \mathrm{m}^{-2} \mathrm{yr}^{-1}$, respectively), while the lowest $\left(0.76 \mathrm{~kg} \mathrm{CaCO}_{3} \mathrm{~m}^{-2} \mathrm{yr}^{-1}\right)$ were in the Back Reef of Playa Blanca. Bioerosion increased rapidly during the first $12 \mathrm{mo}$ and remained constant thereafter. EU mass was rapidly reduced by $50 \%$.
\end{abstract}

KEY WORDS: Bioerosion · Coral reef · Pocillopora spp. $\cdot$ Macroborers $\cdot$ Colombia $\cdot$ Eastern Pacific

\section{INTRODUCTION}

The destruction of calcareous substrate by bioerosion is very important in reef modification due to its persistence in time and space (Trudgill 1983). The balance between this and bioaccretion (the opposite process) generates the final reef morphology (Scoffin et al. 1980, Bak 1994, Reaka-Kudla et al. 1996).

Bioerosion has been extensively studied over the last 2 decades in the western Pacific (e.g. Peyrot-Clausade \& Brunel 1990, Hutchings et al. 1992, Kiene \& Hutchings 1992, 1994, Peyrot-Clausade et al. 1995, Hibino \& van Woesik 2000) and the Caribbean (e.g. MacGeachy \& Stearn 1976, Perry 1998). Conversely, in the tropical eastern Pacific (TEP) bioerosion has been scarce and basically associated to climate changes, e.g. El Niño (Glynn 1990, 1994, Eakin 1992, Reaka-Kudla et al. 1996, Vargas-Ángel et al. 2001). In the TEP, grazers are dominant with few exceptions in which internal bio- erosion has prevailed (e.g. Scott \& Risk 1988, Guzmán \& Cortés 1993, Cortés 1997). For Gorgona Island, studies describe boring mollusks and encrusting sponges (Cantera \& Contreras 1988, Cantera \& Arnaud 1995, Narváez 1999), and others deal with grazers (Glynn et al. 1982, Toro-Farmer 1998, Jimenez 1999, Francisco 2000). However, little is known about the internal process of bioerosion except for that described in the study of Londoño-Cruz (2001).

Bioerosion varies in time and space depending on abiotic conditions (e.g. water turbidity, sedimentation rate, nutrient availability, depth, and distance from shore), and biotic factors (productivity, structural characteristics and zonation of the reef, specific density of different taxa of bioeroders, and solitary or colonial lifestyle of borers). In turn, natural (e.g. extended solar exposure, storms, and El Niño Southern Oscillation [ENSO]) and anthropogenic (e.g. organic pollution, hyper sedimentation, and mechanical damages) per- 
turbations associated with the loss of live tissue have been observed to increase the chance of invasion by bioeroders and consequently the bioerosion process (Macintyre et al. 1992, Reaka-Kudla et al. 1996, Glynn 1997, Wellington et al. 2001).

Branching corals, contrary to massive ones, have been studied relatively little, due perhaps to their shape and size, and the concomitant difficulty in measuring them (in the TEP, internal bioerosion has been cited only by Glynn 1988, Guzmán \& Cortés 1993, Eakin 1996, Londoño-Cruz 2001). This experiment was specially designed to evaluate the effect of borers on branching corals (i.e. excluding the effect of grazers).

We aimed to (1) determine the weight change in the Pocillopora spp. experimental units during 3 different periods of exposure $(6,12$ and $18 \mathrm{mo})$ under natural conditions on the reef; (2) assess if the particular conditions of Gorgona Island reefs (shallowness, high quantity of sediments, very little zonation, frequent air exposure and disturbances) influence bioerosion rates and succession patterns of borer species; and (3) determine which are the main factors causing these differences.
Experimental design. From March 1998 to December 1999, experimental units (EUs) were exposed at the 4 zones in Playa Blanca and at the GP. In Playa Blanca, 3 equidistant transects were set across the reef. Six EU (replicates) were set in every zone for each of 3 different exposure periods $(6,12$ and 18 mo: P1, P2, and P3, respectively). A total of 72 EU were set (6 replicates $\times 4$ zones $\times 3$ periods) at Playa Blanca. GP was treated as a single zone; therefore, $18 \mathrm{EU}$ were set there ( 6 replicates $\times 3$ periods), giving a total of $90 \mathrm{EU}$ used during the whole experiment for the 3 time periods and the 5 sites (BR, FC, RF, RS and GP).

The EU consisted of dead branches of Pocillopora spp. collected from recently broken colonies under natural conditions. Branches were soaked in fresh water and then ground to form a cylinder shape. Cylinders showing signs of bioerosion and/or those that were very different in size were discarded. The initial weight, volume and surface area of each cylinder were recorded; data (mean \pm SD) for the 90 cylinders were: weight $=23.3 \pm 7.1 \mathrm{~g}$, volume $=$ $9.6 \pm 3.8 \mathrm{ml}$, and area $=33.1 \pm 8.1 \mathrm{~cm}^{2}$. A small hole was drilled in 1 end of every EU, and a $1.59 \mathrm{~mm}$ diameter long rod was introduced and cemented using epoxy resin.

\section{MATERIALS AND METHODS}

Study locations. Research was conducted in a fringing reef (Playa Blanca) and a patch reef (Gorgonilla) of Gorgona Island, about $30 \mathrm{~km}$ off the Pacific coast of Colombia (Fig. 1). Gorgona reefs are considered to be among the largest on the southeastern pacific boundary (von Prahl \& Erhardt 1985, Zapata \& Vargas-Ángel 2003). Coral species on Gorgona Island are mostly branching (genus Pocillopora), but some massive species (genera Pavona, Porites and Gardineroseris) as well as Psammocora stellata and Tubastrea aurea also occur. Playa Blanca fringing reef (ca. $112000 \mathrm{~m}^{2}$ ) is located at the southeast end of Gorgona Island. Depth varies between $0.5 \mathrm{~m}$ at low tide in the reef crest (experiencing air exposure in extreme low tides) and $19 \mathrm{~m}$ at high tide in the reef slope. Four zones may be distinguished: Back Reef (BR), Reef FlatCrest (FC), Reef Front (RF), and Reef Slope (RS). Gorgonilla patch reef (GP) is located at a strait known as Paso de Tasca, between Gorgona Island and Gorgonilla Island (a smaller island south of Gorgona). This area is rather shallow, with strong flow and ebb currents (for details see Londoño-Cruz 2001).

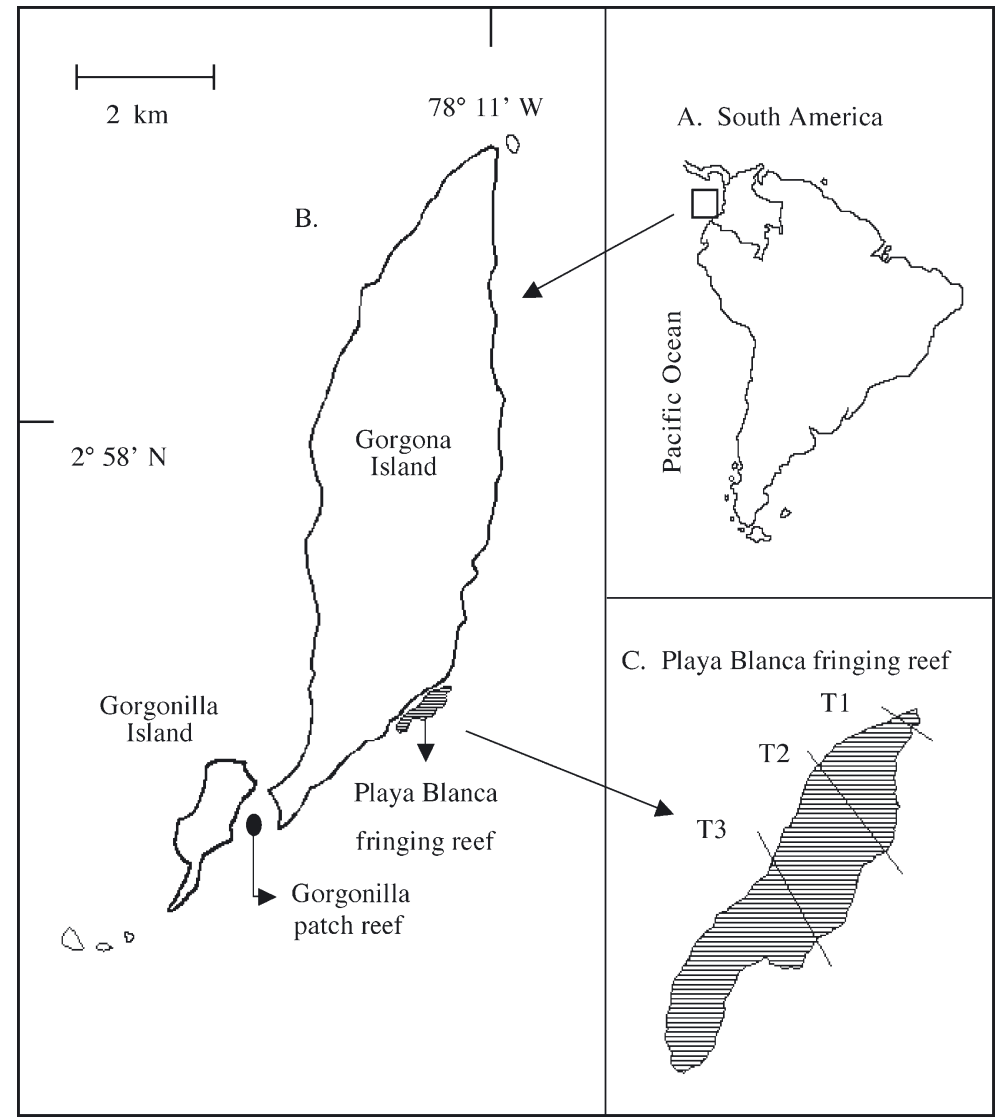

Fig. 1. Map showing (A) location of Gorgona Island in tropical eastern Pacific; (B) location of study sites; and (C) location of transects (T1, T2, T3) in Playa Blanca. Geographic coordinates correspond to Gorgona Island 
At every site, $2 \mathrm{~m}$ long, $6.35 \mathrm{~mm}$ diameter rods were nailed into the framework. Approximately $50 \mathrm{~cm}$ of the rods remained outside the reef bottom and the EUs were fastened to this part using cable ties. EUs were randomly assigned to sites and periods of exposure. Each EU sampled (after 6, 12 or $18 \mathrm{mo}$ ) was stored in situ in a plastic flask fixed in buffered formalin (10\%) after retrieval and stored for further examination. Sedimentation rates, substrate type and coverage, and temperature and depth were measured at the same sites throughout this research. Data will be published in a different paper.

Sea urchins were not able to climb up the rods; they were occasionally seen at the base of the rods, but never any higher. The surface of the rods was too small for the urchins to attach properly, and they were easily washed away by the water. In the case of fishes, even though they had free access to the EUs, we (as well as a research group studying bioerosion by fishes) never observed any attack in situ, and no fish bites were seen during the handling of the EU. We assume that no significant effect, if any, was caused by grazers.

Data analysis. Once all external organisms had been detached, each EU was carefully broken apart using locking pliers and the macroborers then removed, sorted and stored in plastic containers in alcohol (70\%) for further examination. Bivalves were determined to species level when possible, and worms and crustaceans to higher classifications. The remainder of each cylinder was weighed and the loss of $\mathrm{CaCO}_{3}$ was determined by the difference in weight in order to obtain the bioerosion rate $\left(\mathrm{kg} \mathrm{CaCO} \mathrm{Cm}^{-2} \mathrm{yr}^{-1}\right)$.

Regression analysis was performed between initial and removed weight of cylinders for each period (all sites, $n=30$ ) as well as for the combination of period and site $(n=6)$ to evaluate the dependence of bioerosion on cylinder size. Since no dependence was found in any of the cases, cylinder size is not considered to be a source of variation in this experiment. Results were tested using factorial ANOVA (with Time [3 levels] and Site [5 levels] as factors) to evaluate the hypothesis that there were no differences in bioerosion rates over time and space.

\section{RESULTS}

We found at least 5 species of bivalves (genera Lithophaga and Gastrochaena), 3 families of polychaetes (mainly Sabellidae), sipunculid worms and cirripeds of the order Acrothoracica (Table 1). Species of Lithophaga were present in most cylinders (Table 1) and removed the most calcareous substrate, due to their relatively big size and the concomitant big holes they created and/or their relatively high abundance (Fig. 2). These species were the main borer group, especially in GP and RF. Gastrochaena ovata was not as common as Lithophaga spp. but those present were large in size, and therefore must also be considered a major boring agent in this reef. Worms (polychaetes

Table 1. Total number of individuals and, in parentheses, proportion of infested experimental units ( $\mathrm{n}=6 \mathrm{cylinders}$ ) for each site (GP: Gorgonilla patch reef; BR: Back Reef; FC: Reef Flat-Crest; RF: Reef Front; RS: Reef Slope) and period of exposure (6, 12 and 18 mo) for different boring organisms. ( $L=$ Lithophaga; $G=$ Gastrochaena). Blank spaces indicate no organisms found

\begin{tabular}{|c|c|c|c|c|c|c|c|c|c|c|c|c|}
\hline \multirow{2}{*}{ Site } & \multirow{2}{*}{$\begin{array}{c}\text { Exposure } \\
\text { period } \\
(\mathrm{mo})\end{array}$} & & \multicolumn{6}{|l|}{ - Taxon } \\
\hline & & $i^{a^{2}}$ & 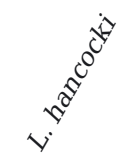 & 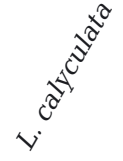 & $\dot{v}^{\sum^{\hbar^{5}}}$ & $\vec{y}^{8}$ & $a_{0}^{a^{2}}$ & $5^{0^{2}}$ & की & 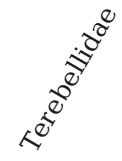 & 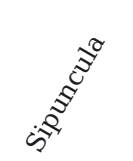 & 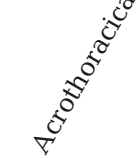 \\
\hline \multirow[t]{3}{*}{ GP } & 6 & $21(0.83)$ & $22(0.67)$ & $6(0.33)$ & & 304 (1) & $1(0.17)$ & $8(0.33)$ & $1(0.17)$ & $4(0.33)$ & $6(0.67)$ & $94(1)$ \\
\hline & 12 & $153(1)$ & $63(1)$ & & & $114(1)$ & & $3(0.33)$ & & & $5(0.83)$ & $1(0.17)$ \\
\hline & 18 & $198(1)$ & $82(1)$ & & $2(0.17)$ & 76 (1) & $1(0.17)$ & & $5(0.5)$ & $3(0.33)$ & $4(0.5)$ & $2(0.33)$ \\
\hline \multirow[t]{3}{*}{ BR } & 6 & & & & & $28(0.67)$ & & & & & $3(0.33)$ & $14(0.67)$ \\
\hline & 12 & $20(0.83)$ & $22(0.67)$ & & $1(0.17)$ & $82(1)$ & $1(0.17)$ & $6(0.33)$ & $1(0.17)$ & & $13(0.67)$ & \\
\hline & 18 & 77 (1) & $29(1)$ & $1(0.17)$ & & $64(1)$ & & & $1(0.17)$ & & $10(0.67)$ & $3(0.33)$ \\
\hline \multirow[t]{3}{*}{$\mathrm{FC}$} & 6 & & & & & $60(0.67)$ & & & $4(0.5)$ & & & 73 (1) \\
\hline & 12 & $34(0.83)$ & $17(0.87)$ & $1(0.17)$ & & $146(1)$ & & $12(0.5)$ & & & $2(0.17)$ & $4(0.33)$ \\
\hline & 18 & $38(1)$ & 27 (1) & $2(0.33)$ & & $66(1)$ & $1(0.17)$ & $2(0.33)$ & $11(0.67)$ & & $8(0.67)$ & $7(0.5)$ \\
\hline \multirow[t]{3}{*}{$\mathrm{RF}$} & 6 & & & & & 99 (1) & $1(0.17)$ & $5(0.5)$ & & & $3(0.5)$ & $42(0.83)$ \\
\hline & 12 & $123(1)$ & $73(1)$ & $3(0.33)$ & $2(0.33)$ & $158(1)$ & $9(0.5)$ & $21(0.83)$ & $19(0.5)$ & & $3(0.17)$ & $181(0.83)$ \\
\hline & 18 & $147(0.67)$ & $45(0.67)$ & $1(0.17)$ & $2(0.33)$ & $77(0.67)$ & & $6(0.5)$ & $11(0.33)$ & & $13(0.17)$ & $35(0.67)$ \\
\hline \multirow[t]{3}{*}{ RS } & 6 & & & & & $20(1)$ & $3(0.33)$ & $24(1)$ & $7(0.17)$ & & $12(0.83)$ & $52(1)$ \\
\hline & 12 & 69 (1) & $60(1)$ & $2(0.17)$ & & 95 (1) & $16(0.5)$ & 53 (1) & $2(0.17)$ & & $11(0.83)$ & 28 (1) \\
\hline & 18 & $79(0.83)$ & $18(0.67)$ & $6(0.83)$ & & $50(1)$ & $6(0.67)$ & $15(0.67)$ & & $3(0.33)$ & $25(0.83)$ & $18(0.67)$ \\
\hline
\end{tabular}




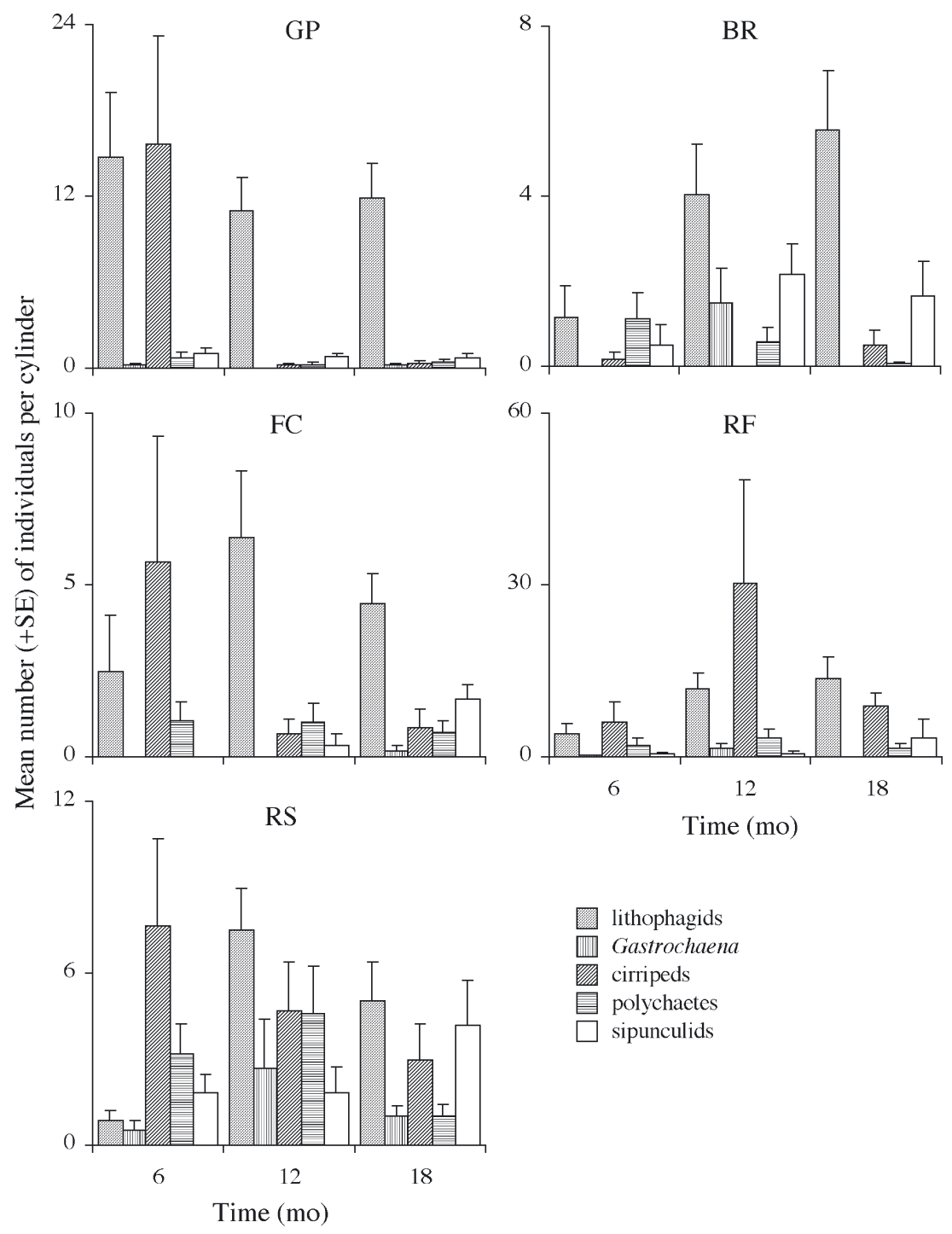

Fig. 2. Mean number $(+\mathrm{SE})$ of individuals of boring organisms through time in Gorgonilla patch reef (GP) and the 4 zones in Playa Blanca: Back Reef (BR); Reef Flat-Crest (FC); Reef Front (RF); and Reef Slope (RS)

and sipunculids) were the least important group, present at low to medium abundances and of relatively small sizes. Both groups were distributed at all sites but sipunculids were generally more common and abundant than polychaetes (Fig. 2). Acrothoracicans were highly abundant, mostly in RF and RS (Fig. 2), and widely distributed (Table 1), mainly during the first exposure period (6 mo), but decreased as time passed.

The ANOVA test for the bioerosion rates showed significant differences among periods $(F=4.80 ; \mathrm{p}=0.011)$ and sites $(F=12.29 ; \mathrm{p}<0.001)$ as well as an interaction between time periods and sites $(F=2.64 ; \mathrm{p}=0.013)$. The post-hoc Tukey test showed that there were significant differences in bioerosion rates between the cylinders of P1 and P2 ( $p=0.032)$ and P1 and P3 ( $p=0.019)$, but there were no differences between cylinders exposed for the longest periods (P2 and P3; $\mathrm{p}=0.977$ ).

GP showed significant differences with BR ( $p<0.001)$, FC $(\mathrm{p}<0.001)$, and RS ( $p<0.001)$ but not with RF $(p=0.255)$. RF showed statistically significant differences with BR $(p<$ $0.001)$ and FC ( $p=0.031)$ but not with RS $(p=0.165)$. There were no significant differences in the bioerosion rates between $\mathrm{BR}, \mathrm{FC}$, and $\mathrm{RS}$. Interactions showed that the highest values were present at GP over 12 and $18 \mathrm{mo}$, followed by RF over 18 and $12 \mathrm{mo}$, and RS over 12 and $18 \mathrm{mo}$. The lowest rates were found at $\mathrm{BR}$ over 12, 6, and 18 mo (Table 2).

The weighed average bioerosion rates for the different periods (i.e. for all 5 sites) showed an increasing pattern through time $(0.9,1.4$ and $1.5 \mathrm{~kg}$ $\mathrm{CaCO}_{3} \mathrm{~m}^{-2} \mathrm{yr}^{-1}$ for 6,12 , and $18 \mathrm{mo}$ respectively). For sites, the highest weighed average bioerosion rate (i.e. the mean for the 3 periods of time) was in the GP $\left(2.0 \mathrm{~kg} \mathrm{CaCO}_{3} \mathrm{~m}^{-2} \mathrm{yr}^{-1}\right)$ followed by RF $\left(1.5 \mathrm{~kg} \mathrm{CaCO} \mathrm{m}^{-2}\right.$ $\mathrm{yr}^{-1}$ ). The other sites showed lower rates and were ranked $\mathrm{RS}, \mathrm{FC}$, and BR. This agrees with the patterns observed from individual sites and periods mentioned above. In summary, bioerosion rates showed an increasing trend in the GP and the RF (and marginally so in the RS) as the time the EUs spent under natural conditions was longer, and there were no significant differences between the most bioeroded sites (GP and RF) during the longer periods (i.e. P2 and P3).

\section{DISCUSSION}

Lithophagid mollusks and sipunculid worms are considered late invaders of carbonate substrates, participating only in the late stages of the bioerosion process (Sammarco et al. 1987, Hutchings et al. 1992). This was not the case in Gorgona. We observed recruits of both lithophagids (around $1.5 \mathrm{~mm}$ ) and sipunculids in EUs exposed for only 6 mo. The high abundance and diversity of lithophagids in this reef (4 species) is comparable to that in Champion Island 
Table 2. Values of bioerosion rates $\left(\mathrm{kg} \mathrm{CaCO}_{3} \mathrm{~m}^{-2} \mathrm{yr}^{-1} \pm \mathrm{SE}\right)$ for the combination of each site and exposure period

\begin{tabular}{|lcc|}
\hline Site & Exposure period (mo) & Bioerosion rate \\
\hline GP & 6 & $1.01 \pm 0.10$ \\
& 12 & $2.58 \pm 0.59$ \\
BR & 18 & $2.51 \pm 0.40$ \\
& 6 & $0.76 \pm 0.04$ \\
& 12 & $0.69 \pm 0.03$ \\
FC & 18 & $0.83 \pm 0.29$ \\
& 6 & $0.96 \pm 0.11$ \\
RF & 12 & $0.93 \pm 0.10$ \\
& 18 & $0.85 \pm 0.31$ \\
& 6 & $0.87 \pm 0.08$ \\
RS & 12 & $1.52 \pm 0.40$ \\
& 18 & $2.00 \pm 0.49$ \\
& 6 & $0.82 \pm 0.08$ \\
& 12 & $1.09 \pm 0.12$ \\
& 18 & $1.09 \pm 0.24$ \\
\hline
\end{tabular}

(Ecuador), where Reaka-Kudla et al. (1996) reported high numbers of lithophagid and rapid bioerosion rates.

Acrothoracicans are rarely reported (Tomlinson 1969). In this study they were abundant, mainly in P1, and their pioneering behavior might be very important in the successional pattern of the boring community of this reef. Polychaetes, unlike what could be considered as the 'typical trend' observed elsewhere (e.g. Hutchings et al. 1992), were rare and small in Gorgona and their relative contribution to net bioerosion is considered to be minor.

Other boring organisms like sponges dominate the internal eroding communities in different parts of the world (e.g. Hein \& Risk 1975, Sammarco \& Risk 1990, Perry 1998). Cryptic boring sponges were seen in coral rubble, but they were absent from our EUs, perhaps due to their elevation from the bottom. Cantera et al. (2003) suggests that the shallowness of these reefs and the high quantity of suspended sediments result in a relative paucity of boring sponges.

In terms of physical characteristics, adequate substrata (i.e. dead coral colonies) where borers can settle, which in turn can be marginally related to borer larvae availability, were more abundant in zones with higher bioerosion rates ( $\mathrm{RF}, 25.5 \%$; $\mathrm{GP}, 23.8 \%$ ) and smaller in other zones (BR, FC and RS). On the other hand, some have found a positive relation between current force and bioerosion rates (Hutchings 1986), while others (e.g. Warme 1975) found the opposite relation; according to Scott (1988), currents have no effect whatsoever in the bioerosion process. Zones with higher bioerosion rates (RF and GP) and higher abundances of lithophagids showed stronger hydrodynamics than the other sites of Gorgona.
The balance between sediment deposition (adverse effect) and nutrient transport (positive effect) is reflected in the diversity and abundance of boring fauna. Sediment load may directly affect the living conditions of borers by deteriorating the habitat for settlement (Sammarco et al. 1987). EUs set in zones with higher sediment load (BR, $811.5 \mathrm{~g} \mathrm{~m}^{-2} \mathrm{mo}^{-1}$; FC, $441.3 \mathrm{~g} \mathrm{~m}^{-2} \mathrm{mo}^{-1}$; and $\mathrm{RS}, 308.6 \mathrm{~g} \mathrm{~m}^{-2} \mathrm{mo}^{-1}$ ) showed lower bioerosion rates relative to zones with lower sediment load $\left(\mathrm{RF}, 191.8 \mathrm{~g} \mathrm{~m}^{-2} \mathrm{mo}^{-1}\right.$; no data for the GP because the sediment traps were dislodged by the strong currents). In terms of depth, we did not find any reasonable association with bioerosion, and consider that in shallow reefs, such as those in Gorgona, depth is a factor of secondary importance (but see Kiene \& Hutchings 1992, 1994, Perry 1998). In short, low sedimentation, high water movement and abundant suitable substrate availability were common in RF and GP, where the EUs were more bioeroded, while the contrary was true for BR, FC and RS.

The specific composition, the number of borers and the bioerosion rates of calcareous and other substrates are determined to a large extent by the time of the year in which the substrate becomes available and by the length of that exposure (e.g. Scott 1988, Hutchings et al. 1992, Kiene \& Hutchings 1994). There was a substantial increment in bioerosion rates after 6 mo of exposure, which agrees with the previous hypothesis. On the other hand, bioerosion studies have required traditionally a considerable lapse of time to draw adequate conclusions, both spatially and temporally (Kiene \& Hutchings 1994). According to our data (see also Reaka-Kudla et al. 1996), it seems that this process operates faster in the TEP than in other regions: over a period no longer than $1.5 \mathrm{yr}$, a $50 \%$ reduction in mass was detected in the EUs used during this experiment.

Additionally, El Niño affects periodically the reefs of the TEP, increasing bioerosion rates as a result of coral mortality and increases in grazer (e.g. urchins) abundances (Glynn 1988, 1990, Eakin 1992, Reaka-Kudla et al. 1996). The high boring rates reported in this paper may also reflect the influence of El Niño 1997-1998. In summary, Gorgona reefs show a different bioerosion pattern compared to reefs elsewhere and in the same biogeographical region. Distinctive features include high abundance of borers (mostly bivalves) and short periods of time to remove considerable amounts of coral from the EUs employed in this study.

Acknowledgements. This project was conducted as part of a research sponsored by COLCIENCIAS (grant 1106-09-069-96) and is a contribution from E.L.-C.'s MSc thesis submitted to Universidad del Valle. We especially thank Raul Neira for his helpful assistance during the field work. Valuable comments of Dr. Zapata and Dr. Bolivar are appreciated and were very important in the improvement of the investigation. We also 
thank the Special Administrative Unit of the System of National Natural Parks (UASPNN), Ministry of the Environment of Colombia, which provided cooperation and assistance during the development of this project; special thanks go to Claudia Acevedo (Director of Gorgona National Natural Park) and biologists G. Mayor and R. Pardo, who greatly supported this study. The manuscript was completed while E.L.-C. was at the Amakusa Marine Biological Laboratory, Sciences Department, Kyushu University; support from Dr. M. Tokeshi is kindly appreciated. We also thank Dr. P. M. Arnaud, Dr. J. Oribe-Stemmer, A. Leone, S. Giordano, G. I. Vargas and 3 anonymous reviewers for their valuable comments which greatly improved the manuscript.

\section{LITERATURE CITED}

Bak RPM (1994) Sea urchin bioerosion on coral reefs: place in the carbonate budget and relevant variables. Coral Reefs 13:99-103

Cantera JR, Arnaud PM (1995) Coral reefs associated molluscan assemblages in Gorgona Island, Colombian Pacific coast. Haliotis 24:87-100

Cantera JR, Contreras RR (1988) Bivalvos perforadores de corales escleractiniarios en la Isla de Gorgona, Pacífico Colombiano. Rev Biol Trop 36:151-158

Cantera JR, Orozco C, Londoño E, Toro-Farmer G (2003) Abundance and distribution patterns of infaunal associates and macroborers of the branched coral (Pocillopora damicornis) in Gorgona island (Tropical Eastern Pacific). Bull Mar Sci 72:207-219

Cortés J (1997) Biology and geology of eastern Pacific coral reefs. Coral Reefs 16 (Suppl):39-46

Eakin CM (1992) Post-El Niño Panamian reefs: less accretion, more erosion and damselfish protection. Proc 7 th Int Coral Reef Symp Guam 1:387-395

Eakin CM (1996) Where are the carbonates gone? A model comparison of carbonate budgets before and after the 1982-1983 El Niño at Uva Island in the eastern Pacific. Coral Reefs 15:109-119

Francisco V (2000) Determinación de las tasas de bioerosión por peces balistidos en un arrecife coralino del Pacífico colombiano. MSc thesis, Universidad del Valle, Cali

Glynn PW (1988) El Niño warming, coral mortality and reef framework destruction by echinoid bioerosion in the eastern Pacific. Galaxea 7:129-160

Glynn PW (1990) Coral mortality and disturbances to coral reefs in the Tropical Eastern Pacific. In: Glynn PW (ed) Global ecological consequences of the 1982-1983 El NiñoSouthern Oscillation. Elsevier, Amsterdam, p 55-126

Glynn PW (1994) State of coral reefs in the Galápagos Islands: natural versus anthropogenic impacts. Mar Pollut Bull 29: $131-140$

Glynn PW (1997) Bioerosion and coral reef growth: a dynamic balance. In: Birkeland C (ed) Life and death of coral reefs. Chapman \& Hall, New York, p 68-95

Glynn PW, von Prahl H, Guhl F (1982) Coral reefs of Gorgona Island, Colombia, with special reference to corallivores and their influence on community structure and reef development. Ann Inst Inv Mar Punta Betín 12:185-214

Guzmán H, Cortés J (1993). Arrecifes coralinos del Pacífico Oriental Tropical: Revisión y perspectivas. Rev Biol Trop 41(3):535-557

Hein FJ, Risk MJ (1975) Bioerosion of coral heads: inner patch reefs, Florida Reef Tract. Bull Mar Sci 25:133-138

Hibino K, van Woesik R (2000) Spatial differences and seasonal changes of net carbonate accumulation on some coral reefs of the Ryukyu Islands. J Exp Mar Biol Ecol 252: $1-14$

Hutchings P (1986) Cryptofaunal communities of coral reefs. Acta Oceanol Sin 5:603-613

Hutchings PA, Kiene WE, Cunningham RB, Donnelly C (1992) Spatial and temporal patterns of non-colonial boring organisms (polychaetes, sipunculans and bivalve mollusks) in Porites at Lizars Island, Great Barrier Reef. Coral Reefs 11:23-31

Jimenez JM (1999) Scarus ghobban (Pises: Scaridae) en la Isla Gorgona (Pacífico Oriental Tropical): abundancia, comportamiento alimenticio y papel en la bioerosión de arrecifes. BSc thesis, Universidad del Valle, Cali

Kiene WE, Hutchings PA (1992) Long-term bioerosion of experimental coral substrates from Lizard Island, Great Barrier Reef. Proc 7th Int Coral Reef Symp Guam 1: 397-403

Kiene WE, Hutchings PA (1994) Bioerosion experiments at Lizard Island, Great Barrier Reef. Coral Reefs 13:19-98

Londoño-Cruz E (2001) Proceso de bioerosión por organismos perforadores en un ecosistema arrecifal del Pacifico Oriental Tropical (Isla Gorgona, Colombia) MSc thesis, Universidad del Valle, Cali

MacGeachy JK, Stearn CW (1976) Boring by macro-organisms in the coral Montastrea annularis on Barbados reefs. Int Rev Ges Hydrobiol 61:715-745

Macintyre IG, Glynn PW, Cortés J (1992) Holocene reef history in the eastern Pacific: mainland Costa Rica, Caño Island, Cocos Island, and Galápagos Island. Proc 7th Int Coral Reef Symp Guam 2:1174-1184

Narváez K (1999) Identificación y aspectos ecológicos de las esponjas del arrecife coralino de Playa Blanca, isla Gorgona (Pacifico colombiano). Tesis de grado, Universidad del Valle, Cali

Perry CT (1998) Macroborers within coral framework at Discovery Bay, north Jamaica: species distribution and abundance, and effects on coral preservation. Coral Reefs 17:277-287

Peyrot-Clausade M, Brunel JF (1990) Distribution patterns of macroboring organisms on Tuléar reef flats (SW Madagascar). Mar Ecol Prog Ser 61:133-144

Peyrot-Clausade M, Le Campion-Alsumard T, Hutchings $P$, Le Campion J, Payri C, Fontaine MF (1995) Initial bioerosion and bioaccretion on experimental substrates in high island and atoll lagoons (French Polynesia). Oceanol Acta 18:531-541

Reaka-Kudla ML, Feingold JS, Glynn W (1996) Experimental studies of rapid bioerosion of coral reefs in the Galapagos Islands. Coral Reefs 15:101-107

Sammarco PW, Risk MJ (1990) Large-scale patterns in internal bioerosion of Porites: cross continental shelf trends on the Great Barrier Reef. Mar Ecol Prog Ser 59:145-156

Sammarco PW, Risk MJ, Rose C (1987) Effects of grazing and damselfish territoriality on internal bioerosion of dead corals: indirect effects. J Exp Mar Biol Ecol 112:185-199

Scoffin JP, Stearn CW, Boucher D, Frydl P, Hawkins CM, Hunter IG, MacGeachy JK (1980) Calcium carbonate budget of a fringing reef of the west coast of Barbados. Bull Mar Sci 30:475-508

Scott PJB (1988) Factors influencing the susceptibility of submarine calcareous substrates to attack by bioeroders. In: Proc 3rd Int Workshop on the Marine Flora and Fauna of Hong Kong and Southern China. Hong Kong University Press, Hong Kong, p 681-691

Scott PJB, Risk MJ (1988) The effect of Lithophaga (Bivalvia: Mytilidae) boreholes on the strength of the coral Porites lobata. Coral Reefs 7:145-151 
Tomlinson JT (1969) The burrowing barnacles (Cirripedia: order Acrothoracica). Bull US Natl Mus No. 296, Smithsonian Inst Press, Washington, DC

Toro-Farmer GA (1998) Estimación de la intensidad bioerosionadora de los erizos (Echinodermata) en un arrecife coralino de la Isla Gorgona-Pacífico colombiano. BSc thesis, Universidad del Valle, Cali

Trudgill ST (1983) Measurements of rates of erosion of reefs and reef limestones. In: Barnes DJ (ed) Perspectives on coral reefs. Australian Institute of Marine Science, series contribution no. 200. B. Clouston, Manuka, p 256-262

Vargas-Ángel B, Zapata FA, Hernandez H, Jimenez JM (2001) Coral and coral reef responses to the 1997-98 El

Editorial responsibility: Otto Kinne (Editor),

Oldendorf/Luhe, Germany
Niño event on the Pacific coast of Colombia. Bull Mar Sci 69:111-132

von Prahl H, Erhardt H (1985) Colombia Corales y Arrecifes Coralinos. FEN Colombia, Editorial Presencia, Bogotá

Warme JE (1975) Boring as trace fossils, and the processes of marine bioerosion. In: Frey RW (ed) The study of trace fossils. Springer, Berlin, p 181-229

Wellington GM, Glynn PW, Strong AE, Nauarrete SA, Wieters E, Hubbard D (2001) Crisis on coral reef linked to climate change. EOS Trans Am Geophys Union 82:1-7

Zapata FA, Vargas-Ángel B (2003) Corals and coral reefs of the Pacifc coast of Colombia. In: Cortés J (ed) Latin American coral reefs. Elsevier-Science, Amsterdam, p 419-447

Submitted: July 29, 2002; Accepted: November 25, 2003

Proofs received from author(s): December 15, 2003 